\title{
Stefan Zweig, Balzac. Il romanzo della sua vita
}

\section{Marco Stupazzoni}

\section{(Q) OpenEdition}

\section{Journals}

\section{Edizione digitale}

URL: http://journals.openedition.org/studifrancesi/5384

DOI: $10.4000 /$ studifrancesi.5384

ISSN: 2421-5856

\section{Editore}

Rosenberg \& Sellier

\section{Edizione cartacea}

Data di pubblicazione: 1 dicembre 2016

Paginazione: 544

ISSN: 0039-2944

\section{Notizia bibliografica digitale}

Marco Stupazzoni, « Stefan Zweig, Balzac. I/ romanzo della sua vita », Studi Francesi [Online], 180 (LX I

III) | 2016, online dal 01 janvier 2017, consultato il 18 septembre 2020. URL : http://

journals.openedition.org/studifrancesi/5384; DOI : https://doi.org/10.4000/studifrancesi.5384

\section{Questo documento è stato generato automaticamente il 18 settembre 2020.}

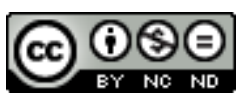

Studi Francesi è distribuita con Licenza Creative Commons Attribuzione - Non commerciale - Non opere derivate 4.0 Internazionale. 


\title{
Stefan Zweig, Balzac. Il romanzo della sua vita
}

\author{
Marco Stupazzoni
}

\section{NOTIZIA}

STEFAN ZWEIG, Balzac. Il romanzo della sua vita, traduzione di Lavinia Mazzucchetti.

Prefazione di Renzo Paris, Roma, Ellint, 2015, «Manubri», 334 pp.

1 Pubblicato postumo, nel 1946, quattro anni dopo il suicidio dell'autore, questo Balzac di Stefan Zweig si annovera tra i classici della critica balzachiana di ogni tempo. Gli anni giovanili vissuti nell'umiliante contesto claustrofobico del collegio, l'oppressione della madre, i primi tentativi commerciali e letterari, i grandi amori, le disastrose speculazioni finanziarie, la nascita e l'evoluzione del titanico progetto romanzesco della Comédie humaine, la solitudine del morente, sono alcune tra le tematiche più rilevanti che attraversano il testo nel corso dei ventisei capitoli che formano la struttura dell'opera.

2 Tuttavia, per usare le parole di Roland Barthes, che Renzo Paris puntualmente riprende nella sua pregevole prefazione al testo, il Balzac di Zweig sfugge dagli stretti vincoli imposti dall'erudizione critica per imporsi al lettore come un vero e proprio romanzo («ogni biografia è un romanzo che non osa dire il suo nome», scrive Barthes in $S / Z$, cit. p. 5): un romanzo, osserva Paris, che «presenta un ritmo leggero, mozartiano, bene inciso in quel realismo atmosferico cui accennava Auerbach» (p. 7). 